Journal of Environmental Sciences (JES)

Institute of Environmental Studies and Research, Ain Shams University

Shaiboon et al.

\title{
ADVANCED PHOTOCATALYTIC DEGRADATION OF RED WATER FROM TNT MANUFACTURING
}

\author{
Sarwat Sh. Mohammed ${ }^{(1)}$; Eisa E. Hekal ${ }^{(2)}$; Noha S. Donia ${ }^{(3)}$ \\ Ashraf A. Ismail ${ }^{(4)}$
}

1) Abu-Zaabal Company for special chemicals 2) Faculty of Science, Ain Shams University 3) Institute of Environmental Studies and Research, Ain Shams University 4) Technology center of Excellence (STCE), Ministry of Military production

\begin{abstract}
The disposal of waste water (red water) that produced during the production of TNT in an environmental acceptable manner posses serious difficulties. For many years this red water were disposed of by the method open burning but the method is not acceptable today owing to the effect of particulates, nitrogen oxide and other harmful products which pollute the air. Some other methods of incineration are available which overcome part of these difficulties, but they are very costly. Preliminary experiments using the method of adsorption on the locally produced activated carbon have demonstrated that adsorption alone is not enough to fulfill the lowest possible levels of total organic carbon (TOC) and chemical oxygen demand (COD) for red water treatment. In the experimental work the measure of extent of treatment, is the percentage removal at wavelength $200 \mathrm{~nm}$, also TOC and COD before and after treatment were measured. Pre-treatment by adsorption demonstrated that, the percentage removal at wavelength $200 \mathrm{~nm}$ is $76 \%, 70 \%$ TOC and $78 \%$ COD. The aim of this work is the usage of advanced oxidation process (AOP) by $\mathrm{UV} / \mathrm{H}_{2} \mathrm{O}_{2}$ to fulfill the lowest possible levels of TOC and COD. The treated water after manipulation of the proposed technique of advanced oxidation process (AOP) was $95.7 \%$ TOC and 97\% COD.

The preceding results reflect that the used technique is promising and the red water after treatment can be discharged safety.

Keywords: Red water; Adsorption; Advanced oxidation process $\left(\mathrm{UV} / \mathrm{H}_{2} \mathrm{O}_{2}\right)$.
\end{abstract}


J. Environ. Sci

Instituteof Environmental Studies and Research, Ain Shams University

El Sherbiny, Hanan et al

\section{INTRODUCTION}

The symmetrical 2,4,6-trinitrotoluene $(\alpha-\mathrm{TNT})$ is one of the most important and widely used explosives. The manufacture of TNT consists of two main processes: nitration of toluene to crude TNT and TNT purification to remove any unsymmetric TNT isomers (for example, 2,3,5-TNT, 2,4,5TNT). During the purification stage, sodium sulfite is added to react with the unsymmetric TNTs, resulting in the formation of dinitrotoluene (DNT) sulfonated compounds (for example 2,4-DNT-5-SO3Na). These sulfonates are water soluble and are easily separated from $\alpha$-TNT. The wastewater resulting from the purification process exhibits an intense "red" color and is commonly referred to as TNT red water. In addition to the DNT sulfonated compounds, red water also contains products of complete nitration (for example, priority pollutants 2,4-DNT and 2,6-DNT) and complex byproducts formed during the nitration and purification stages. Currently, red water is classified by US Environmental protection Agency (EPA) as a Resource Conservation and Recovery Act (RCRA)-regulated hazardous waste (K047) based on its reactivity. Furthermore, TNT and red water are toxic to aquatic life. (Burrows et al., 1989)

Consequently, the treatment and disposal of red water presents a significant environmental problem for the public and private sectors involved in the manufacturing of TNT. 
Because of the complicated nature of red water, conventional biological treatment, carbon adsorption, chemical precipitation, fractional distillation, and ozonation are ineffective for red water-treatment.

The treatment of wastewater or ground water from military ammunition plants or other such facilities contaminated with various nitro- compounds such as trinitrotoluene dinitrotoluene, RDX, HMX and tetryl etc. has been well studied using different types of activated carbons (Bauman et al., 1990).

As a whole, adsorption is a simple-to-operate process and relatively costeffective, due to (or no) energy requirements. Adsorption parameters can by simply established by using an appropriate isotherm equation.

The last decade has witnessed advanced oxidation processes (AOPs) emerging as promising alternatives to tertiary treatment, owing to their high potency to render partial and ultimate destruction of many refractory compounds including dyestuff-halogenated and aromatic organics (Ince and Tezcanli (1999); Tomaszewski et al., (2003). These processes involve the formation of highly reactive free radical species, which are far more powerful as oxidizing agents than commonly known strong oxidants like molecular oxygen and ozone. The chemistry, kinetics and quantum yields in free radical reactions have been widely investigated and reviewed in the paste (Glaze et al., 1987).

These processes have two unique advantages over other advanced treatment processes; (i) they are non-selective to a very broad range of chemicals, and (ii) they involve no sludge production due to the character of 
their removal mechanism, which is based on the oxidative destruction of organic carbon by conversion to higher oxidation states.

It is our interest to make use of the coupling techniques (Adsorption and AOPs) in treatment of TNT manufacturing red water. In this concern, two types of carbons were tested simultaneously. The optimal conditions were obtained and the non-adsorbed pollutants remaining in bulk after filtration was further treated using $\mathrm{UV} / \mathrm{H} 2 \mathrm{O} 2$.

\section{EXPERIMENTAL}

Instrumentation: A Hewlett Packard Diode array spectrophotometer (Model 8451A) was used to measure the UV-Vis absorbance for raw and treated water samples. A microprocessor $\mathrm{pH}$ meter HANNA model HI-9321 was used for $\mathrm{pH}$ measurement. A water bath shaker of American optical corporation (Buffalo, New York) was used for all the adsorption experiments. Dohraman, model DC-190 was used for TOC measurement. COD was determined according to standard methods (APHA1985) Standards methods for the examination of water and wastewater, 16th edition, American Public Health Association, Washington, DC. Inductively coupled plasma-Emission Spectrometry (ICP-ES) Perkin Elmer optima 3000 was used to detect the trace metals and cations. The IR spectra of synthesized activated carbon were recorded using FTIR 1725X (Perkin Elmer) spectrophotomers. Elemental analyses were carried out on a Perkin-Elmer $2400 \mathrm{CHN}$ elemental analyzer. 
The laboratory-scale thermostated pyrex glass-column photoxidation reactor is used [Fig. 1]. The procedure was carried out batchwise under illumination of a single 400 WHQL high pressure mercury vapor lamp (Phillips) whose protective cover was removed. The reactor was waterjacketed to keep solution temperature at $25^{\circ} \mathrm{C}$ for all runs.

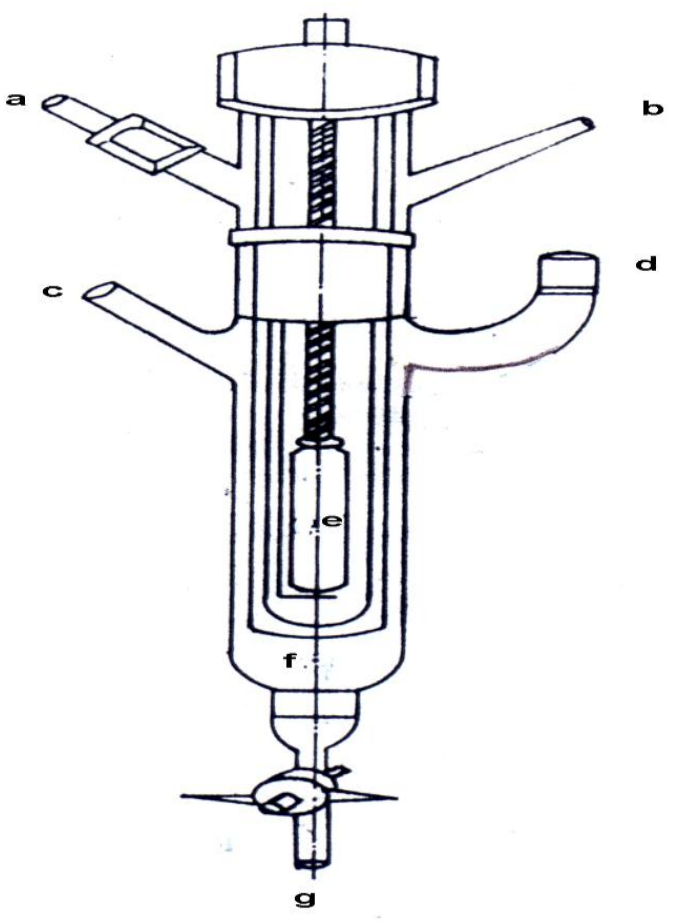

Fig. (1): Photo oxidation reactor: a: cooling water inlet, b: cooling water outlet, c: gas inlet (nitrogen), d: gas outlet (nitrogen), e: UV lamp, f: sample solution and g: sampling stopcock. 
J. Environ. Sci

Instituteof Environmental Studies and Research, Ain Shams University

El Sherbiny, Hanan et al

\section{MATERIALS}

\section{Pre-treatment by adsorbents: two types of adsorbents were used:}

- Discard bone charcoal (BC) residue from Pakin Co., Egypt, was tested. This local biomass derived material is of animal origin. The $(\mathrm{BC})$ residue is the resultant of pyrolysis process occurred according to the following conditions:

\footnotetext{
$800^{\circ} \mathrm{C}-5 \mathrm{hrs}$

Animal bones $\longrightarrow(\mathrm{BC})$ residue + steams + oil + ammonia liquor
}

The residu un unum was varies according to the type of animal (e.g. camel, buffalo or cattle) and its food. The BC residue is left in an inert atmosphere to avoid any oxidation. Then, it is crushed and sieved to give constant particle sizes used for different purposes. The remaining size from sieving (30 mesh) is considered as carbidge i.e. waste of no use. This waste is used as an adsorbent in our study. A characterization of BC is presented elsewhere (Daifullah et al., 1997).

- The activated carbon (AC) prepared from rice husk (RH), according to the method presented elsewhere (Shokry et al., 2004).

Adsorbate: The red water was obtained from a TNT manufacturing plant, from Abu-Zaabal company for Specialty Chemicals. The red water was filtered through cotton, placed in dark bottle and stored in a refrigerator at $4^{\circ} \mathrm{C}$. The prolonged refrigeration, however, produced crystalline flakes. The samples was kept at room temperature and thoroughly mixed using a magnetic stirrer to redissolve the crystals before each experiment. 
A typical red water composition is shown in Table 1.

Only diluted raw red water (1:100) was used in all of the adsorption experiments, and (AOPs), primarily for safety reasons.

Table (1): Red water composition (Hao et al., 1992)

\begin{tabular}{|c|c|c|}
\hline Parameter & Working Value & Reference Value \\
\hline \hline $\mathrm{pH}$ units & 7.3 & 7.6 \\
\hline COD & 535.4 & 685 \\
\hline TOC & 355.4 & 544 \\
\hline
\end{tabular}

All concentration results in $\mathrm{mg} / \mathrm{L}$ based on diluted red water $(1: 100)$, unless otherwise noted.

Method: Photo oxidation using $\mathrm{UV} / \mathrm{H}_{2} \mathrm{O}_{2:}$ In general, the procedures were performed by mixing $\mathrm{BC}$ and $\mathrm{AC}$ simultaneously in a ratio of $4: 1$ with $50 \mathrm{ml}$ of red water and shaken for $12 \mathrm{hrs}$ at $\mathrm{pH} 2$. Then, the filtrate was used to study the parameters affecting the photo oxidation (e.g. exposure time and hydrogen peroxide amount). All samples before and after photo oxidation were analyzed for TOC, COD and the absorbance at $\lambda_{\max } 200,346,362,432$ and $488 \mathrm{~nm}$ was determined spectrophotometrically.

Analytical methods: This work concerned with compound specific test using UV spectrophotometer and non-specific tests using total organic carbon (TOC), chemical oxygen demand (COD).

Total organic carbon (TOC): TOC was measured using total organic analyzer (Dohrman, model DC-190) with a non-dispersive infrared detector (NDIR). The sample is homogenized, acidified with $5 \% \mathrm{H}_{3} \mathrm{PO}_{4}$ and diluted as necessary and a microportion is injected into a heated reaction chamber 
backed with an oxidative catalyst such as cobalt oxide. The water is vaporized and the carbon is oxidized to $\mathrm{CO}_{2}$ and $\mathrm{H}_{2} \mathrm{O}$. The $\mathrm{CO}_{2}$ from oxidation of organic and inorganic carbon is transported in the carrier gas streams and is measured by means of a non-dispersive infrared analyzer. Potassium hydrogen phthalate standards $(0.2-10 \mathrm{mg} / \mathrm{L})$ were used for sample calibration.

Chemical oxygen demand (COD): A sample of $2 \mathrm{ml}$ was heated at $150^{\circ} \mathrm{C}$ for two hours with strong oxidizing agent $\mathrm{K}_{2} \mathrm{Cr}_{2} \mathrm{O}_{7}$. Oxidizable organic compounds react, reducing the dichromate ion $\left(\mathrm{Cr}_{2} \mathrm{O}_{7}\right)^{2-}$ to green chromic ion $\left(\mathrm{Cr}^{3+}\right)$. The amount of chromic ion produced is measured colorimetrically to determine the chemical oxygen demand.

Trace metals and cations: Trace elements such as $\mathrm{Co}, \mathrm{Ni}, \mathrm{Zn}, \mathrm{Cd}, \mathrm{Pb}, \mathrm{Fe}$, $\mathrm{Mn}, \mathrm{Al}, \mathrm{Cu}$, and $\mathrm{Cr}$, were analyzed using the inductively coupled plasmaemission spectrometry (ICP-ES) is Perkin Elmer optima 3000 with ultrasonic nebulizer (USN). This nebulizer increases the sensitivity of the instrument. Also, soluble cation such as $\mathrm{Ca}^{2+}, \mathrm{Mg}^{2+}, \mathrm{Na}^{+}, \mathrm{P}^{3+}, \mathrm{B}^{3+}$ and $\mathrm{K}^{+}$, were analyzed, using ICP-ES by direct aspiration using pneumatic nebulization using cross flow nebulizer (Charles et al., 1997)

UV-Vis absorbance: The UV-vis spectrophotometric data were used to notice trends on organics removal or accumulation, based on the comparison of absorption intensities for raw and treated water samples at different wavelengths $(200 \mathrm{~nm}, 362 \mathrm{~nm}$ (representing an abundance of aromatic compounds content of the TNT red water), the unknown byproducts where 
the raw red water exhibits absorbance at (432, 346 and $488 \mathrm{~nm}$ ) (Hao et al., 1992).

\section{RESULTS AND DISCUSSION}

Pre-treatment by adsorption technique: Factors affecting adsorption process of nitro organic compounds (red water) using mixed carbon $(\mathrm{AC}+\mathrm{BC}))$ were determined. Also the minimum contact time, the minimum adsorbent dose and the exact $\mathrm{pH}$ of the solution were determined (Shokry et al., 2004). The percent removal (\% R) of nitro-organics compound assigned in the TNT red water before and after the treatment using mixed carbon is determined and listed in Table (2).

Table (2): Concentrations of nitro-organics compound in raw red water (1:100) before and after treatment using adsorption technique at optimum conditions (pH: 2; contact time: $12 \mathrm{hrs} ; 1 \mathrm{~g} \mathrm{AC}+0.25 \mathrm{~g} \mathrm{BC}$ )

\begin{tabular}{|c|c|c|c|}
\hline \multirow{2}{*}{ Parameter } & \multicolumn{2}{|c|}{ Concentration $\left(\mathbf{m g ~ l}^{\mathbf{- 1}}\right)$} & \multirow{2}{*}{ Removal (\%) } \\
\cline { 2 - 3 } & Before treatment & After treatment & \\
\hline \hline TOC & 355.42 & 106.6 & 70 \\
\hline COD & 535.4 & 117.78 & 78 \\
\hline Wavelength(nm) & & & 76 \\
\hline 200 & 1.7 & 0.4 & 70 \\
\hline 346 & 3.2 & .0 .96 & 72 \\
\hline 362 & 2.7 & 0.75 & 72 \\
\hline 432 & 2.9 & 0.81 & 78 \\
\hline 488 & 1.2 & 0.26 & \\
\hline
\end{tabular}

As shown from Table (2), the concentration of total nitro-organics in the effluent waste waters needs to be brought down so as to meet a low interim discharge limit of $1 \mathrm{ppm}$ of total nitro bodies (Effluent standards for environmental pollutants, US chemical industry digest consultancy, special issue 
II 1991).This means that, the pre-treatment by adsorption using mixed carbon $(\mathrm{AC}+\mathrm{BC})$ is insufficient for treatment red water, so that the per oxidation systems ( $\mathrm{UV} / \mathrm{H}_{2} \mathrm{O}_{2}$ ) is used to fulfill the lowest level of TOC and COD.

Effect of mixed carbon $(\mathrm{BC}+\mathrm{AC})$ on the removal of metal ions: It is worth to mention that the adsorption process using mixed carbon $(\mathrm{BC}+\mathrm{AC})$ will affect the removal of metal ions as well as organic content. In this concern, the percent removal $(\% \mathrm{R})$ of the metal ions assigned in the TNT red water before and after the treatment using mixed carbon is determined using ICP and listed in Table (3).

Table (3): Concentrations of metals in raw red water (1:100) before and after treatment using adsorption technique ( $\mathrm{pH}$ : 2; contact time: $12 \mathrm{hrs}$; $1 \mathrm{~g} \mathrm{BC}+0.25 \mathrm{~g} \mathrm{AC})$

\begin{tabular}{|c|c|c|c|}
\hline \multirow{2}{*}{ Metal } & \multicolumn{2}{|c|}{ Concentration $\left(\mathbf{m g ~ l}^{\mathbf{1}}\right)$} & \multirow{2}{*}{ Removal (\%) } \\
\cline { 2 - 3 } & Before treatment & $\mathbf{A f t e r}$ treatment & \\
\hline \hline $\mathrm{Cd}^{++}$ & 0.001 & 0.0001 & $90 \%$ \\
\hline $\mathrm{Ba}^{++}$ & $\mathrm{ND}$ & $\mathrm{ND}$ & \\
\hline $\mathrm{Co}^{++}$ & $\mathrm{ND}$ & $\mathrm{ND}$ & $85 \%$ \\
\hline $\mathrm{Cr}^{+++}$ & 0.041 & 0.006 & $95 \%$ \\
\hline $\mathrm{Cu}^{++}$ & 0.043 & 0.002 & \\
\hline $\mathrm{Fe}^{+++}$ & 0.059 & 0.059 & \\
\hline $\mathrm{Mn}^{++}$ & $\mathrm{ND}$ & $\mathrm{ND}$ & \\
\hline $\mathrm{Ni}^{++}$ & $\mathrm{ND}$ & $\mathrm{ND}$ & $72 \%$ \\
\hline $\mathrm{Pb}^{++}$ & 0.05 & 0.014 & \\
\hline $\mathrm{Sb}^{+++}$ & 0.03 & 0.03 & \\
\hline $\mathrm{Se}^{++++}$ & $\mathrm{ND}$ & $\mathrm{ND}$ & \\
\hline $\mathrm{Ti}^{++++}$ & $\mathrm{ND}$ & $\mathrm{ND}$ & \\
\hline $\mathrm{V}^{+++++}$ & $\mathrm{ND}$ & $\mathrm{ND}$ & \\
\hline $\mathrm{Zn}^{++}$ & 0.049 & 0.016 & \\
\hline $\mathrm{Hg}^{++}$ & $\mathrm{ND}$ & $\mathrm{ND}$ & \\
\hline $\mathrm{As}^{++}$ & $\mathrm{ND}$ & $\mathrm{ND}$ & \\
\hline \hline
\end{tabular}


ND: Non-detected

Advanced oxidation process (AOP): The degradation of the dissolved organic compounds which are not adsorbed on either (BC) or (AC), was further treated using AOP. In this concern, factors affecting the oxidation (e.g. the amount of oxidant $\mathrm{H}_{2} \mathrm{O}_{2}$; the exposure time) are assessed.

Effect of $\mathrm{H}_{2} \mathrm{O}_{2}$ amounts: The presence of $\mathrm{H}_{2} \mathrm{O}_{2}$ has a great influence for the reduction of organic concentration in water. Moreover, it was the necessary to decide the amount of $\mathrm{H}_{2} \mathrm{O}_{2}$ to fulfill the lowest possible value of total organic carbon (TOC) and chemical oxygen demand (COD). This is due to the much higher $\mathrm{H}_{2} \mathrm{O}_{2}$ concentration will be (1) economically undesirable (Jerome et al.,1994).and (2) scavengers for hydroxyl radicals (Shen et al., 1996) The residual $\mathrm{H}_{2} \mathrm{O}_{2}$ in solution was determined by potassium iodide (KI) titration method (Snell and Ettre et al., 1987) As expected, the COD, TOC and UV absorbance at 200, 346, 362, 432, and $488 \mathrm{~nm}$ results are a function of $\mathrm{H}_{2} \mathrm{O}_{2}$ dosages were shown in figure (2), whereby efficiency increases with increasing $\mathrm{H}_{2} \mathrm{O}_{2}$ dosage until the ratio between the amount of oxidant to the amount of the filtrate after adsorption, $\mathrm{H}_{2} \mathrm{O}_{2}$ : contaminant, was $\approx 1: 8$ to achieve the $84-85 \%$ TOC, $85-86$ COD and $80 \%$ as a percent removal calculated by UV absorbance. The COD, TOC (Fig.3) and UV-absorbance results (Fig.2) indicate essentially the same phenomena. 
J. Environ. Sci

Instituteof Environmental Studies and Research, Ain Shams University

El Sherbiny, Hanan et al

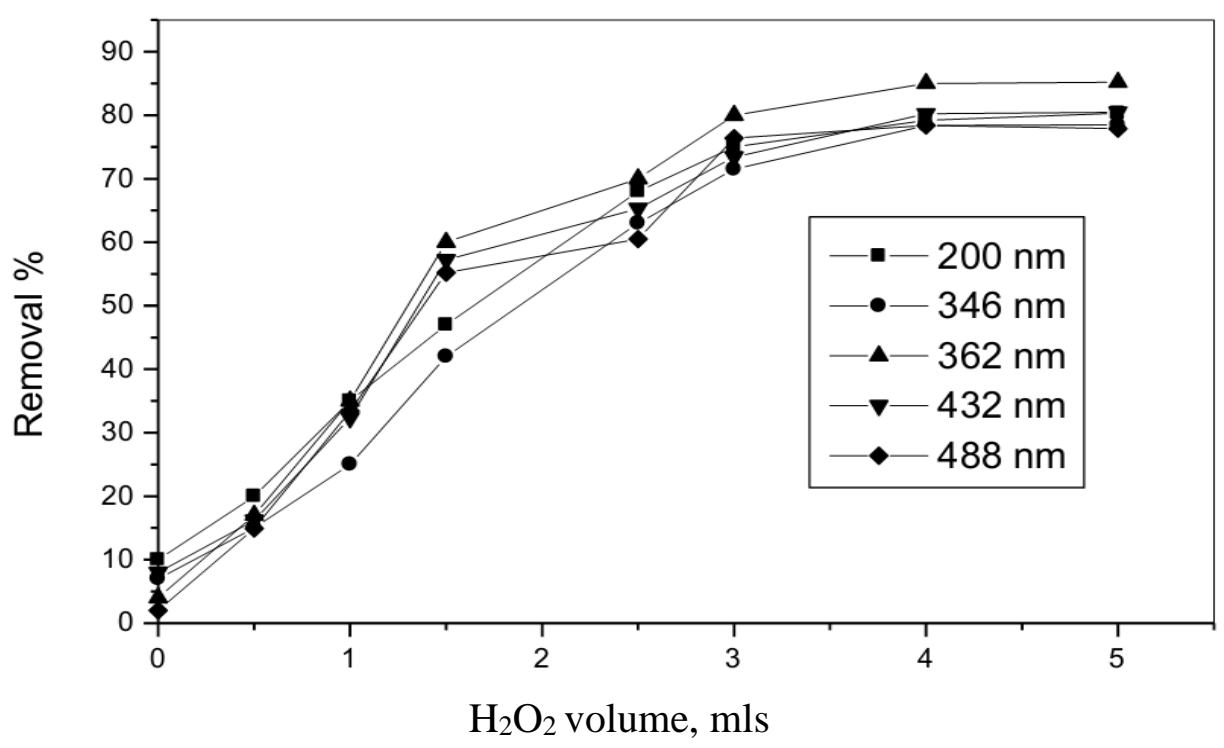

Fig. (2): Effect of $\mathrm{H}_{2} \mathrm{O}_{2}$ dosage on the percent removal of TNT red water from UV measurements.

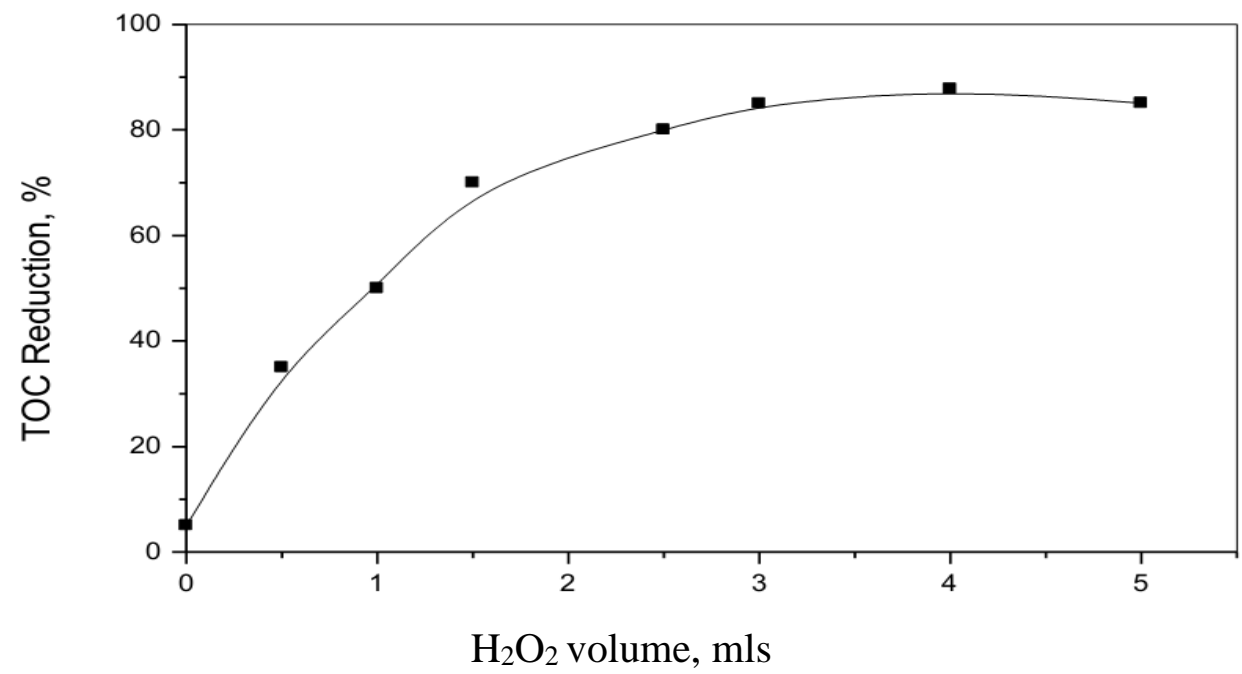

12

Vol.(49); Iss.(1); No.(1); Jan.2020

ISSN $1110-0826$ 


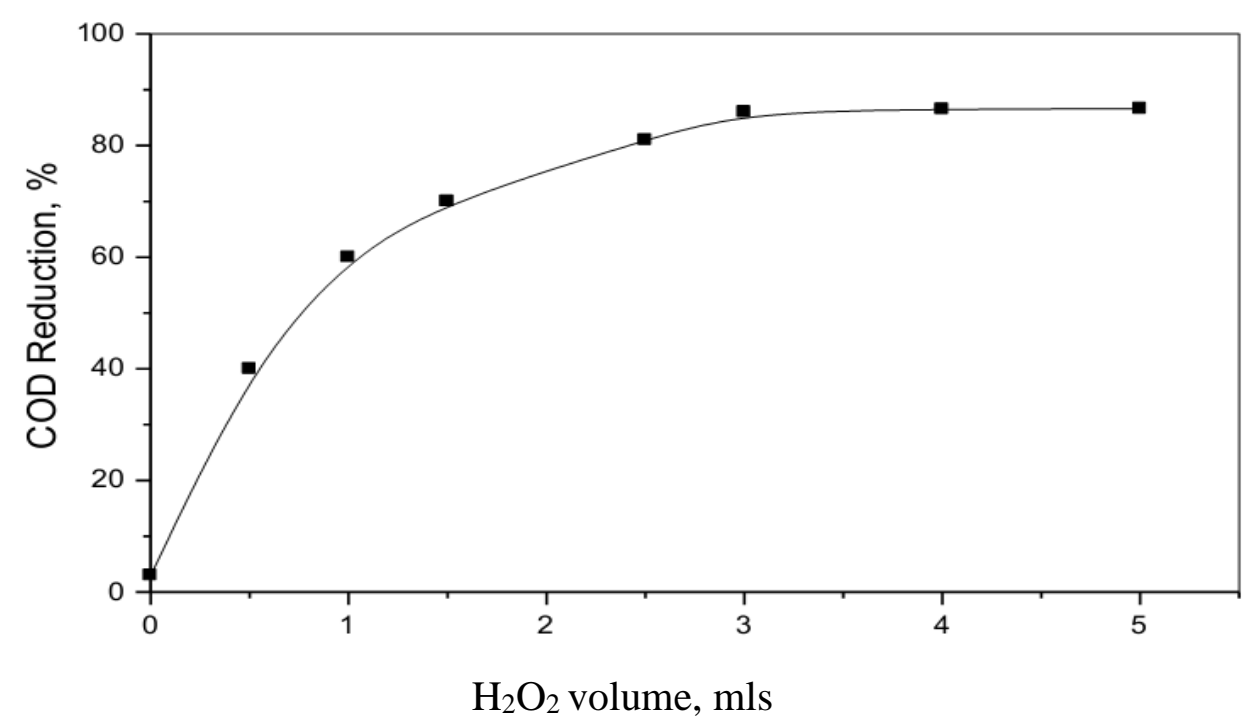

Fig. (3): Effect of $\mathrm{H}_{2} \mathrm{O}_{2}$ dosage on the percent removal of TNT red water from TOC and COD measurements.

Effect of UV-exposure time: Photolysis of $\mathrm{H}_{2} \mathrm{O}_{2}$ is the most direct method for the generation of hydroxyl radicals, which may be described by the following equation:

$\mathrm{H}_{2} \mathrm{O}_{2}+\mathrm{hv} \longrightarrow 2 \mathrm{OH}$

The excited hydrogen peroxide molecule is cleaved into two hydroxyl radicals, then, these radicals initiate the chain decomposition (Scheck C. K. and Frimmel F. H. (1995).

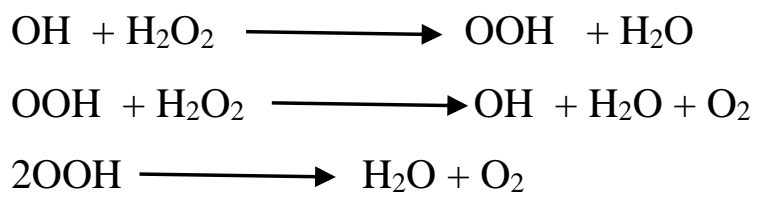


The destruction of red water was rapid (Figs. $4 \& 5$ ). After two hours of exposure time there was a $81.4 \%$ reduction in TOC, $83.8 \%$ reduction in COD and $88.1 \%$ reduction UV-absorbance at $200 \mathrm{~nm}$. The solution $\mathrm{pH}$ decreased from 2.15 to 1.2 . The red water has little buffer capacity and the reduction in $\mathrm{pH}$ indirectly infers that $\mathrm{SO}_{3}$ groups were rapidly detached from the DNTs, resulting in the formation of $\mathrm{H}_{2} \mathrm{SO}_{4}$. (i.e. acidity increases). Also, the formation of new components due to AOP may also cause the reduction in $\mathrm{pH}$ from 2.15 to 1.2 .

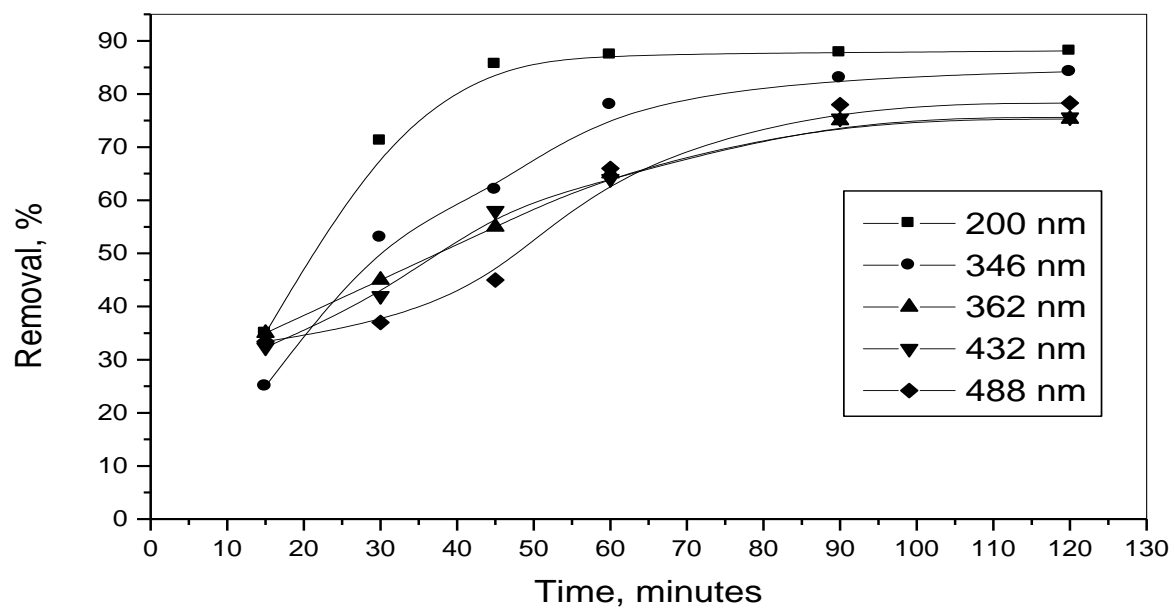

Fig. (4): Effect of exposure time on percent removal of TNT red water from UV measurements $\left(25 \mathrm{ml}\right.$ Filtrate $+3 \mathrm{ml} \mathrm{H}_{2} \mathrm{O}_{2}$ exposed to UV irradiation for $2 \mathrm{hrs}$ ). 
Journal of Environmental Sciences (JES)

Institute of Environmental Studies and Research, Ain Shams University

Shaiboon et al.
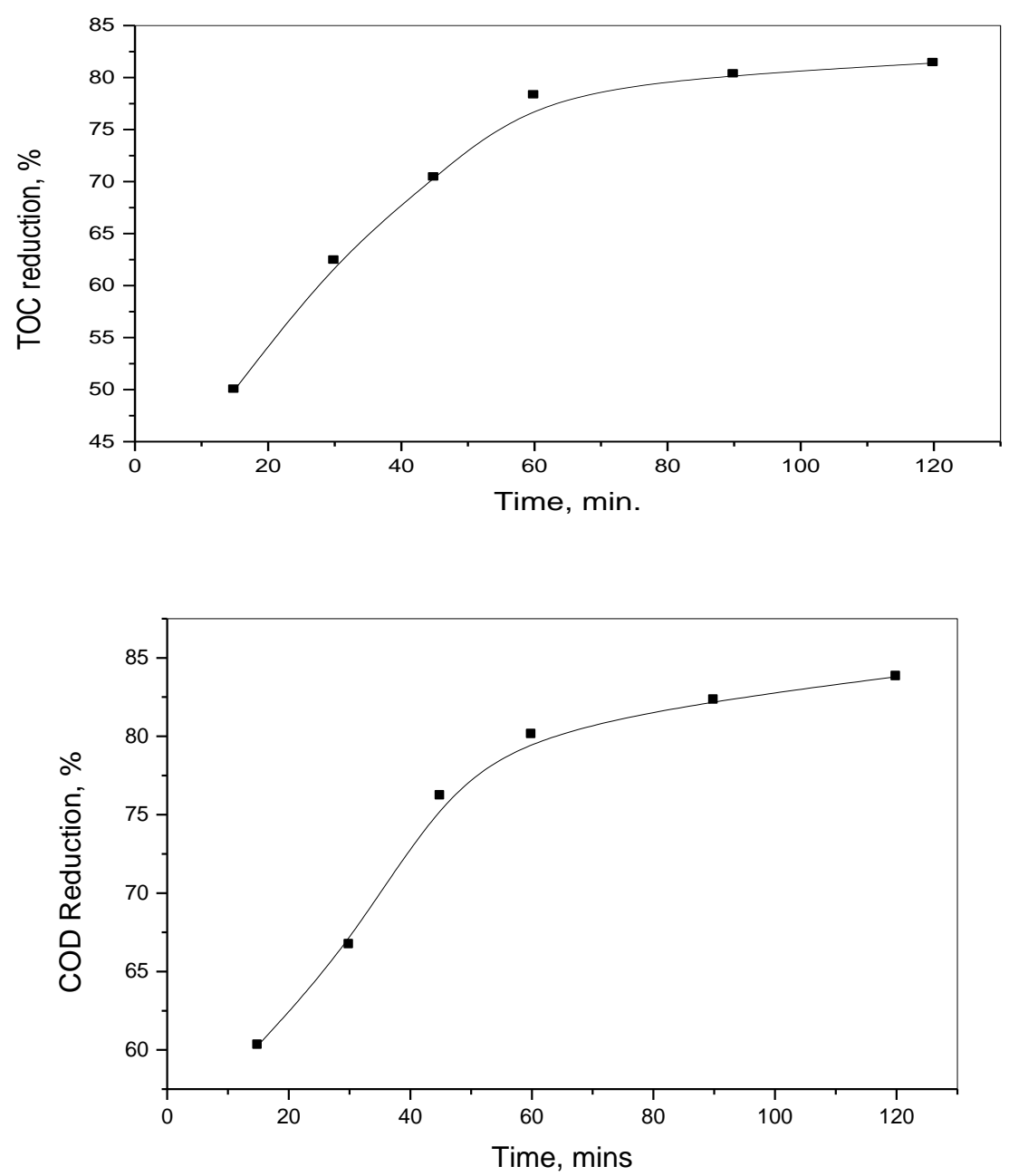

Fig. (5): Effect of exposure time on percent removal of TNT red water from TOC and COD measurements $\left(3 \mathrm{ml} \mathrm{H}_{2} \mathrm{O}_{2}\right.$ exposed to $\mathrm{UV}$ irradiation for $2 \mathrm{hrs}, 200 \mathrm{~nm}$ ) 


\section{CONCLUSION}

After the treatment of the waste water by adsorption on mixing carbons $(\mathrm{BC}+\mathrm{AC})$, the removal by total organic carbon $\mathrm{TOC}$ is $71 \%$ and chemical oxygen demand COD is $78 \%$, but to achieve the lowest permissible level of nitrobody concentration in a treated effluent, the advanced oxidation process $\mathrm{UV} / \mathrm{H}_{2} \mathrm{O}_{2}$ was used as a most promising system for a more complete mineralization of organic carbon. It was found that the total removal by combination of adsorption and advanced oxidation $\left(\mathrm{UV} / \mathrm{H}_{2} \mathrm{O}_{2}\right)$ was TOC 95.7\%; COD 97\%.

The system described herein provides apparent advantages over single operated adsorption systems. These processes have two unique advantages over other advanced treatment processes: (i) they are non-selective to a very broad range of chemicals, and (ii) they involve no sludge production due to character of their removal mechanism, which is based on the oxidative destruction of organic carbon by conversion of the higher oxidation states.

Treatment of red water from TNT manufacture using adsorption / AOP proves its efficiency in removal of organic as well as heavy metals and the treated water can pass into river without any risk health effects.

\section{REFERENCES}

APHA (1985): Standards methods for the examination of water and wastewater, $16^{\text {th }}$ edition, American Public Health Association, Washington, DC. 
Bauman L. C. and Stenstrom M. K. (1990): Removal of organohalogens and organohalogen precursors in reclaimed wastewater, Wat. Res, 24 (8), 949.

Burrows W. D. (1982): Tertiary treatment of effluent from Holston, Army Ammnunition plant, US Army Armanent R. \& D. Command, Dover, NJ, Report No. 8207.

Burrows E. P. (1989): Organic explosives and related compounds; Environmental and Health Considerations. Technical Report 8901, U.S Army Biomedical Research Development Laboratory, Fort Detrick, Md.

Charles B. B. and Kenneth J. F. (1997): Concepts, instrumentation, and techniques in inductively coupled plasma optical emission spectrometry, $2^{\text {nd }}$ edition.

Daifullah A. A. M.; El-Reefy S. A. and Gad H. M. H. (1997): Optimization of Ultrasonic Irradiation as an Advanced Oxidation Technology, Ads. Sci \& Technol., 15(7), 845

Glaze, W. H.; Kang, J. W. and Chapin, D. H. (1987): The chemistry of water treatment processes involving ozone, hydrogen peroxide and ultraviolet radiation, Ozone Sci. Eng. 9, 335.

Guittonneau, S.; De laat, J.; Duguet, J. P.; Bonnel, C. and Dore, B. (1990): Oxidation of PCNM in dilute aqueous solutions by $\mathrm{O}_{3}+\mathrm{UV}$ and $\mathrm{H}_{2} \mathrm{O}_{2}+\mathrm{UV}$ : a comparative study, Ozone Sci., Eng. 12, 73-94.

Güral, M. D. and Vatista, S. R. (1987): Oxidation of Phenolic Compounds by ozone and ozone/UV radiation: A comparative study, Water Res. 21(8), 895.

Hao, O. J.; Phull, K. K.; Davis, A. P.; Chen, J. H. and Maloncy, S. W. (1992): Evaluation of wet air oxidation of TNT red water, Proce $24^{\text {th }}$ MidAtlantic Ind. Waste Conf. Morgantown WV. Technomic, Lancaster. PA, p. 110-119.

HOPC and DAWCS (1988): Environmental Technol., 22919. 
Ince, N. H. (1998): Light enhanced chemical oxidation for tertiary treatment of municipal landfill leachate, Water Env. Res. 70(6), 1161-1168.

Ince, N. H. and Tezcanli, G. (1999): Treatability of textile dyebath effluents by advanced oxidation: Preparation for reuse, Wat. Sci. Tech. 40 (1), 183-190.

Ince, N. H.; Stephen, M. I. and Bolton, JR. (1997): UV/ $\mathrm{H}_{2} \mathrm{O}_{2}$ degradation and toxicity reduction of textile azo dyes, J. Adv. Oxid. Technol. 2(3), 442-448.

Jerome, O. N. and Milagross Simmons (1994): Environmental oxidants, John Wiley \& sons, Inc., USA p. 534.

Kusakab, K.; Aso, S.; Wada, T.; Hayashi, J.; Moroka, S. and Isomuta, K. (1991): Destruction rate of volatile organochlorine compounds in water by ozonization with ultraviolet radiation, Water Res. 25 (10), 1199.

Ledoda, V. V.; Turov, W.; Tomaszewski, V. M.; Gun'ko, J. and Skubiszewska-Zieba (2002): Effect of adsorption of nitroaromatic compounds on the characteristics of bound water layers in aqueous suspensions of activated Carbon 40, 389-396.

Nay, M. W. (1974): Biological treat ability of trinitrotoluene manufacturing wastewater. J. Water pollut. Control Fed, 46, 485.

Rajagopal, J. C. Kapoor (2001): Development of adsorptive removal process for treatment of explosives contaminated wastewater using activated carbon, Journal of hazardous materials B87 73-98 .

Scheck, C. K. and Frimmel F. H. (1995): Degradation of phenol and salicylic acid by ultraviolet radiation /hydrogen peroxide/oxygen, Wat. Res. 29, 2340-2352.

Shen, Y. Ku. and Lee, K.C. (1996): Decomposition of chlorophenols in aqueous solution by $\mathrm{UV} / \mathrm{H}_{2} \mathrm{O}_{2}$ process, Toxicological \& Environmental Chemistry, 14, 51-54. 
Shokry, S. A; Sayed, S. A.; Daifullah, A. A. and Ismail, A. A.: $35^{\text {th }}$ international annual conference of ICT, June $29^{\text {th }}-$ July $2^{\text {nd }}, 2004$, P.85

Smock, L. A. (1976): The toxic effects of trinitrotoluene (TNT) and its primary degradation products on two species of Algae and the fathead minnow. Water Res. (G.B), 10, 537-542.

Snell, F. D. and Ettre, L. S. (1987): Encyclopedia of industrial chemical analysis, John Wiely \& sons, Inc., New York, 24, 427.

Stachelin, J. and Hoigne, J. (1985): Decomposition of ozone in water in the presence of organic solutes acting as promoters and inhibitors of radical chain reactions, Env. Sci. of Technol., 19,1206.

Tomaszewski, W.; Gun'ko, V. M.; Skubiszewska-Zieba, J. and Leboda, R. (2003): Structural characteristics of modified activated carbons and adsorption of explosives, Journal of Colloid and Interface Science, 266, 388-402. 


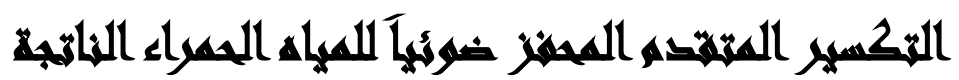

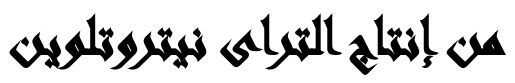

\section{ثروت شيبون محمد علام(')- عيسى السيد هيكل(ז)- نهى سمير دنيا(r)

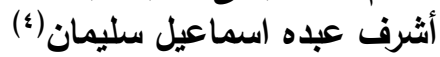

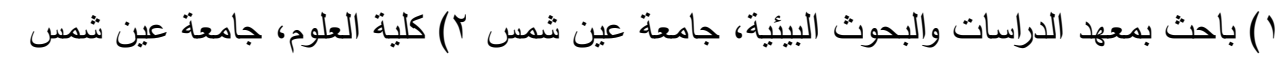

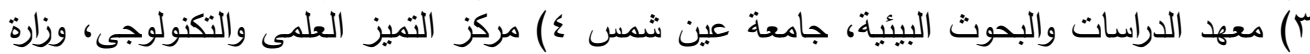

\section{المستطلص}

ان التخلص من مياه الصرف الصناعى (المياه الحمراء) الناتجة من انتاج التراى نيتروتلوين

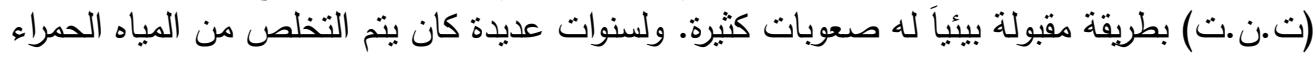

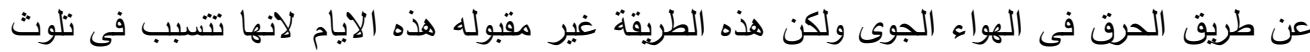
الهواء بالعوالق واكاسيد النيتروجين والمواد الخطيرة الاخرى. وتهدف هذه التهن الدراسة الى استخدام الأكسدة

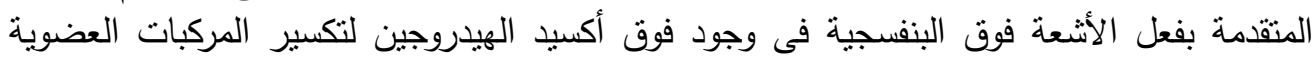

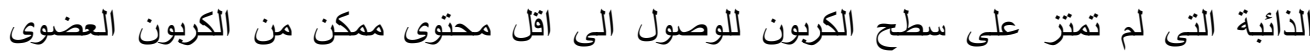

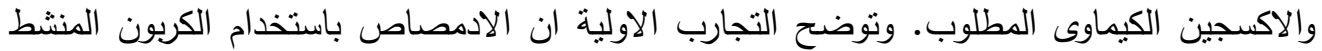

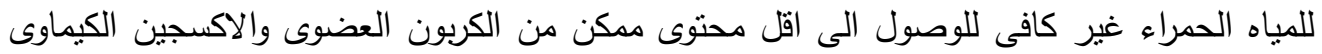

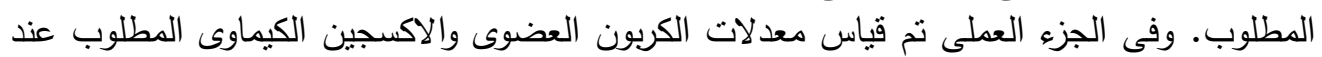

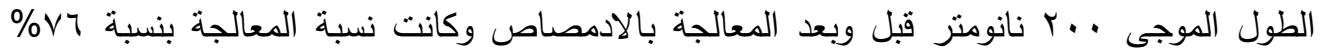

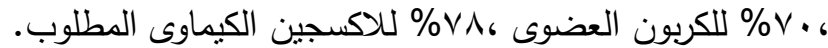

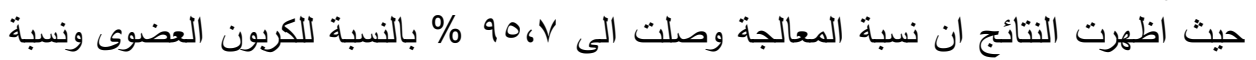

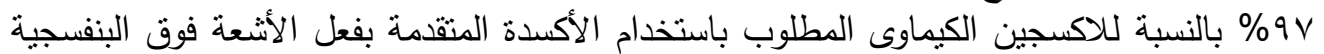

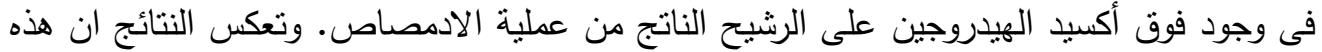

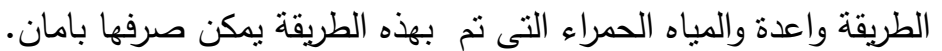

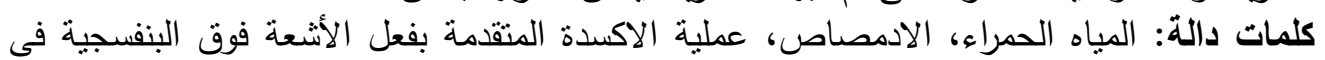
وجود فوق أكسيد الهيدروجين. 